Volume 11

Issue 3 Global Approaches to Atrocity

Prevention: Theory, Practice, and the State of

Article 6 the Field

3-2018

\title{
Germany's Politics and Bureaucracy for Preventing Atrocities
}

\author{
Sarah Brockmeier \\ Global Public Policy Institute \\ Philipp Rotmann \\ Global Public Policy Institute
}

Follow this and additional works at: https://digitalcommons.usf.edu/gsp

\section{Recommended Citation}

Brockmeier, Sarah and Rotmann, Philipp (2018) "Germany's Politics and Bureaucracy for Preventing Atrocities," Genocide Studies and Prevention: An International Journal: Vol. 11: Iss. 3: 20-31.

DOI:

http://doi.org/10.5038/1911-9933.11.3.1582

Available at: https://digitalcommons.usf.edu/gsp/vol11/iss3/6

This Articles is brought to you for free and open access by the Open Access Journals at Digital Commons @ University of South Florida. It has been accepted for inclusion in Genocide Studies and Prevention: An International Journal by an authorized editor of Digital Commons @ University of South Florida. For more information, please contact digitalcommons@usf.edu. 
Germany's Politics and Bureaucracy for Preventing Atrocities

\author{
Sarah Brockmeier \\ Global Public Policy Institute \\ Berlin, Germany \\ Philipp Rotmann \\ Global Public Policy Institute \\ Berlin, Germany
}

\begin{abstract}
Germany has accepted the unique responsibility arising from its history. The avoidance of war and violence in international relations, the prevention of genocide and severe violations of human rights, and the defence of endangered minorities and the victims of oppression and persecution are integral to Germany's reason of state. ${ }^{1}$
\end{abstract}

As of June 2017, this is official German government policy, adopted by the federal cabinet as the highest executive organ in its "Guidelines on Preventing Crises, Resolving Conflicts, Building Peace." Compared to earlier policy documents, the ambition is expressed more strongly than ever: raison d'état, or reason of state, is vernacular usually reserved for Germany's unwavering commitment to the survival of the state of Israel.

The statement quoted above must be seen in the context of Germany's broader coming of age in matters of international leadership. It does not describe the emphasis on preventing genocide and mass atrocities in current policy. Interpreting this aspiration and its prospects for shaping future policy requires substantial background on the past and present of Germany's political debates and bureaucratic infrastructure on crisis prevention, atrocity prevention, and responsibility to protect.

This paper consists of two main sections. The first introduces the political context and recent history of Germany's institutional setup for atrocity prevention. The second describes this setup and explains its strengths and weaknesses, as well as the key challenges to be addressed in order to live up to the aspiration of making more effective contributions to the prevention of genocide and other atrocities. We conclude with an outlook on Germany's contributions to atrocity prevention in the next few years.

\title{
Context: Debates on Prevention and Intervention in Germany
}

Atrocity prevention as a distinct category in German political debates is fairly new and still rarely used. Over the past 15 years, the issues that were discussed in the US as atrocity prevention were linked either to the responsibility to protect (R2P) or to conflict prevention, which is referred to as "crisis prevention" in the German debate. ${ }^{2}$ Part of the reason for this is evident in the language. There is no consistent, agreed-upon phrase for "mass atrocities" in German. However, the two debates about R2P and conflict prevention have been almost completely disconnected from one another: the R2P debate is tainted by its association with military intervention, while the conflict prevention debate is shaped by an emphasis on long-term, structural peacebuilding with civilian means. Accordingly, atrocity prevention is almost never treated as a category in itself, and there is little awareness of the differences between conflict and atrocity prevention. ${ }^{3}$

"Never Again What?" Contradicting Historical Lessons at the Center of the Prevention Debate Key to comprehending German views on all three categories - R2P, conflict prevention and atrocity prevention - is understanding the societal and historical debates in Germany on these topics. This

\footnotetext{
${ }^{1}$ German Federal Government, Guidelines on Preventing Crises, Resolving Conflicts, Building Peace, July 21, 2017 (German Federal Foreign Office), accessed December 31, 2017, www.diplo.de/guidelines.

2 The German policy community uses the term "crisis prevention" ("Krisenprävention") where most English speaking experts would use conflict prevention. The German usage comes with many conceptual debates on its own.

${ }^{3}$ Gregor Hofmann, „Politische Bekenntnisse ohne Folgen,“ HSFK Standpunkte 6 (2013), 6.
} 
is linked to Germany's own history and the Holocaust, but also the history of the peace movement and its role in shaping the internationalist left. The distinct meaning and use of the pivotal term "never again" in Germany illustrates a key difference to the United States.

In the US, genocide prevention advocates, Holocaust survivors, and high-ranking politicians regularly draw comparisons between the Holocaust and mass atrocities in Rwanda, Srebrenica, Darfur or Syria. ${ }^{4}$ Historical responsibility, in that interpretation, includes not only remembering the past but also fighting mass atrocities today.

In Germany, the phrase "never again" is used in two ways. First, to refer to "never again war," the conclusion drawn from the responsibility for two World Wars that expresses the core of the pacifist streak in mainstream German society. Second, where "never again" is used in reference to the Holocaust ("never again Auschwitz"), it is usually interpreted as a responsibility to prevent right-wing ideology, racism, and fascism in Germany. When, in 1999, then-foreign minister Joschka Fischer used "never again Auschwitz" to mobilize support for the military intervention in Kosovo, he was heavily criticized for abusing the phrase and diminishing the singularity of the Holocaust. Since then, politicians hardly ever make such connections. In the German peace movement, including significant parts of the foreign policy community from the left of the political spectrum, the Kosovo intervention is still hugely controversial.

In 2001, the International Commission for Intervention and State Sovereignty that developed the idea of a responsibility to protect actually had a prominent German member. Klaus Naumann had recently retired as the Chairman of the NATO Military Committee and previously served as the Inspector-General, effectively the Chief of Staff, of the German Bundeswehr. Known as a passionate advocate for muscular intervention in the Balkans, Naumann was put in charge of the chapter on military options by the Commission. The German government, however, did everything to ignore that Naumann existed: the defense department refused to meet or even reply to his requests for guidance, and the Foreign Office directed him to junior officials who received his occasional reports about the proceedings but refused to provide him with any insight into the considerations of the government on the matter. ${ }^{5}$

It took a whole decade, as well as a controversial German vote in the UN Security Council, to bring the R2P debate home. Beginning in 2005, when the UN General Assembly endorsed a version of R2P, German policymakers treated the concept as a legal norm in the making that required German support at the level of the European Union and the United Nations, mostly in the sense of including the words "responsibility to protect" in statements and resolutions. ${ }^{6}$ In 2011, Germany's controversial abstention on a resolution authorizing an intervention in Libya triggered the first genuinely public debate on R2P in Germany. ${ }^{7}$ Mainstream newspapers published editorials on R2P's origin and purpose, and parties in the Bundestag voiced their support for R2P in party motions. In this context, German policymakers began to see R2P as not only international law in the making, but also a moral principle and a practical commitment that needs operationalization.

The dominant links to Kosovo and Libya, however, exemplify the bias in the public perception of atrocity prevention in Germany. To this day, every debate about preventing or stopping atrocities gets short-circuited into a debate about military intervention. Whatever the political decision, whether Germany refuses to employ military force, as in Libya, or whether it breaks a longstanding taboo and delivers military assistance, as in Iraq in 2014, as soon as the military question is settled, the debate ends. How best to use and equip German armed forces for such interventions, or which other diplomatic, economic, or judicial tools the German government has at its disposal, is hardly ever subject to public or even expert discussion.

\footnotetext{
${ }^{4}$ See, for example, Elie Wiesel, "Genocide Prevention Initiative Launch" (speech, Washington, DC, April 23, 2012), United States Holocaust Memorial Museum, accessed February 20, 2018, https://www.youtube.com/watch?v= xTGJxYp76w.

${ }^{5}$ Interviews with former German policymakers, Berlin, Summer 2013.

${ }^{6}$ Sarah Brockmeier, Gerrit Kurtz, and Julian Junk, “Emerging Norm and Rhetorical Tool: Europe and a Responsibility to Protect," Conflict, Security and Development 14, no. 4 (2014), 448-449.

${ }^{7}$ Sarah Brockmeier, "Germany and the Intervention in Libya," Survival Global Politics and Strategy 55, no. 6 (2013), 63-90.
} 
Little Civil Society and Political Pressure

The open public dispute over Germany's lessons from history may also partly explain why the German public and civil society advocacy are relatively listless and lackluster on atrocity prevention. Whereas US reforms on atrocity prevention have been significantly driven by civil society mobilization, there is no comparable NGO infrastructure devoted to the issue in Germany. Most internationalist civil society organizations, including religious and human rights groups, build on an anti-imperialist, often pacifist tradition of opposing American interventions during the Cold War and beyond. They advocate for human rights and peace in general, but hardly any of them work on atrocity prevention specifically. Instead of embracing R2P as an advocacy tool, most of them see the principle primarily as a back-door attempt to legitimize military adventures. There are very few exceptions: Genocide Alert, Crisis Action, Human Rights Watch Germany, and the Society for Threatened Peoples are the main groups. ${ }^{8}$ In contrast to the US, Germany does not have large-scale advocacy campaigns pressuring the government to take action on particular country cases or to improve its atrocity prevention tools.

All of this makes atrocity prevention an unattractive and even difficult issue for political leaders to support. Most of the prominent or semi-prominent politicians who do support a stronger German leadership role on atrocity prevention prefer to do so quietly, rather than championing the issue in public and risking to alienate voters.

In the European Union as a whole, dynamics are similar. Although a large number of groups are committed to peace and human rights, the topic of atrocity prevention does not play a substantial role in major human rights organizations. ${ }^{9}$ There are also fewer political entrepreneurs, such as Samantha Power, who alternate between civil society and bureaucracy. Compared to the United States, political elites and the bureaucracy in both Germany and the European Union are less open to exchange with academia and civil society in general.

These differences between the United States and the European Union are exemplified by a comparison between the results of the U.S. Genocide Prevention Task Force (GPTF) and the fate of the attempted European replica, the Task Force on the EU Prevention of Mass Atrocities. ${ }^{10}$ The EU Task Force, in 2012, provided a thorough assessment of the EU's strengths and weaknesses on mass atrocity prevention and provided a list of recommendations to European institutions on how to improve the institutional set-up of the EU (some of which we repeat below). Yet while many of the GPTF's recommendations were taken up by the Obama administration, the EU Task Force's report seems to have largely been forgotten shortly after its presentation in early 2013 . The key difference between the EU and the US version of the reports was not the quality of their content, but the political clout of their drafters. The most important feature of the Genocide Prevention Task Force was its composition, a veritable who's who of credible foreign and security policy experts, chaired by Madeline Albright and William Cohen. This was vital to its acceptance as an objective among Washington's political elite. The European equivalent, initiated by a Hungarian NGO, failed to receive such high-level political backing for its work - a reflection of the differing conditions for promoting mass atrocity prevention between the US and the European Union.

\section{Recent Growth in Responsibility}

Despite the shortcomings in the political and societal context for atrocity prevention debates in Germany and the EU, Berlin's role in the world and willingness to take on responsibility has been growing. This has important side effects for atrocity prevention, as we will show in the next section.

\footnotetext{
${ }^{8}$ One of the authors was a board member of Genocide Alert from 2010 to 2015. More information on Genocide Alert's work can be found at http://www.genocide-alert.de.

${ }^{9}$ Chiara De Franco, Christoph O. Meyer, and Karen E. Smith, “'Living by Example?' The European Union and the Implementation of the Responsibility to Protect (R2P)," Journal of Common Market Studies 53, no. 5 (2015), 994-1009.

${ }^{10}$ Budapest Centre for the International Prevention of Genocide and Mass Atrocities, The EU and the Prevention of Mass Atrocities - An Assessment of Strengths and Weaknesses (Hungary: Foundation for the International Prevention of Genocide and Mass Atrocities, February 2013), accessed December 31, 2017, http://massatrocitiestaskforce.eu/Report files/The EU and the prevention of mass atrocities - an assessment of strenghts and weaknesses.pdf.
} 
For a long time, Germans have seen events in distant war zones as something that does not concern them. This has been changing. The 2015 refugee crisis confronted many previously unconcerned Germans with the reality of wars and atrocities in far-away places. Chancellor Angela Merkel summarized this tendency in an unusually candid fashion in the fall of 2015: "In many regions war and terror prevail. States disintegrate. For many years we have read about this. We have heard about it. We have seen it on TV. But we had not yet sufficiently understood that what happens in Aleppo and Mosul can affect Essen or Stuttgart. We have to face that now."11

German support of the negotiations with Iran, Berlin's central role in addressing the crisis in Ukraine, its decision to arm the Kurdish Peshmerga in their fight against IS as well as its support of the anti-IS coalition with up to 1200 German troops are all signs that Germany is taking increasing responsibility. Polls show unprecedented backing for this approach. In annual polling about public attitudes toward security issues, record numbers of Germans reported that they now support an active role in addressing the problems, crises and conflicts of the world. After 2000, support for this question usually lingered between the mid-40s and mid-50s; in many years, there was essentially a tie between supporters and opponents of an active role. In 2014, the picture changed. Suddenly, there were clear majorities in favor: support jumped to 59\%, then $66 \%$ (2015) and then $63 \%$ (2016), with fewer than $35 \%$ opposed each year. ${ }^{12}$

In this context of growing international ambitions, based on a foundation of growing public support, the last administration issued two new foundational documents about Germany's international posture. In the summer of 2016, a new defense white paper was issued, while a year later, in the summer of 2017, guidelines on "Preventing Crises, Resolving Conflicts, Building Peace" followed. Both documents broke new ground in placing Germany's responsibility for international peace and security in the context of its historical past. In so doing, the government has begun to turn a powerful argument that had previously been used mostly to support restraint and passivity into a justification, even a requirement, for the country to play a more active role.

Both documents are formally of equal status, adopted by the entire cabinet as the highest organ of the executive, and both are meant to express a cross-party consensus that should hold for the next five to ten years, regardless of changes in government. At the same time, German security policy continues to be lopsidedly biased toward territorial and alliance defense, and the defense white paper - which does not go into any kind of detail on atrocity prevention - is thus seen as significantly more important than the guidelines. The effective political weight of the guidelines remains to be seen in the coming years.

\section{Germany's Institutional Setup for Atrocity Prevention}

Who Owns Atrocity Prevention? Inter-agency Coordination

The administration of Germany's international relations is based primarily on the country's parliamentary system of government and an electoral system that usually leads to coalition governments. Germany's Basic Law firmly enshrines the "Ressortprinzip" (usually translated as "departmental principle") that grants a high degree of autonomy and responsibility to individual ministries. Compared to many other Western democracies, these legal foundations and the decades of political custom built on them have produced an unusually weak role for the Chancellery in any but the top-tier foreign policy issues of the day. The day-to-day policymaking process is supposed to be coordinated by the Foreign Office but on any overlapping policy issues, its leadership role is often challenged by either the Defense or the Development Ministry. In contrast to almost any other country in the world, the latter is a separate ministry, independent from the Foreign Office.

These general observations have a number of implications for atrocity prevention. First, Germany's Federal Security Council is largely defunct as a policy-making forum on international

\footnotetext{
${ }^{11}$ Karl Vick and Simon Shuster, "Time Person of the Year: Chancellor of the Free World," TIME, December 9, 2015, accessed December 31, 2017, http://time.com/time-person-of-the-year-2015-angela-merkel/.

${ }^{12}$ Markus Steinbrecher, et al., Security and Defense Policy Opinion climate in the Federal Republic of Germany (Potsdam: Centre for Military History and Social Sciences of the German Armed Forces, 2016), accessed December 31, 2017, http://www. mgfa-potsdam.de/html/einsatzunterstuetzung/downloads/161124kurzberichtbevoelkerungsumfragezmsbw2016.pdf.
} 
security; its main role is to take decisions about arms exports. On conflict prevention and peacebuilding, the existing working level coordination group has done little more than facilitate information exchange between various ministries. There is no other cabinet-level forum to coordinate international security or prevention issues, not even a single deputies-level forum with this kind of broad mandate. After years of constant squabbling, the cabinet decided in June 2017 to pilot a "coordination group for crisis prevention, stabilization and peacebuilding" among directors-general (roughly equivalent to undersecretaries in the U.S. administration). Its future under the new administration depends on the arrangements and decisions to be taken by the next government.

Second, given these structural challenges, there is little inter-agency strategy development on conflict prevention and stabilization in general, let alone atrocity prevention. In addition, so far, German political leaders across all ministries lack an overview of the tools available for atrocity prevention. What is still missing is an inter-agency review that could provide an overview of existing instruments and capabilities and that not only refers to the tools of the Foreign Office and the Ministry of Defense, but also include the contributions by the Development Ministry, intelligence services, as well as the Ministries of Justice, Finance and the Interior.

\section{Conflict Prevention, Stabilization and R2P in the Foreign Office}

If there is no structure akin to the Atrocities Prevention Board coordinating inter-agency prevention initiatives, is there at least an individual in any of the ministries responsible for such coordination? In the fall of 2012, the German foreign office named the deputy director of its UN division the R2P focal point. However, successive focal points have mostly viewed themselves as the German representative at international focal point meetings organized by the Global Centre for the Responsibility to Protect. None of the German focal points of the past five years considered themselves responsible for looking inward and examining how the German government could improve its coordination and improve its tools for atrocity prevention. ${ }^{13}$

The relative neglect of R2P stands in stark contrast to the huge build-up of resources for "crisis prevention, stabilization, peacebuilding and humanitarian aid," which is the name of an entirely new directorate-general created in 2014. As of 2017, it has more than 100 staff and an annual budget of more than 2 billion euro, the largest part of which is being spent on humanitarian aid. After the most recent reshuffling in the summer of 2017, there is now a division for "strategic foresight, early warning, scenario planning, R2P and civilian experts" as part of the new directorate-general. It supports the R2P focal point and seeks to keep track of atrocity risks as part of its broader early warning and early action efforts (see below).

The Foreign Office has long funded projects for what is known as civilian crisis prevention - usually without a link to an explicit conflict analysis or strategy process, but rather based on suggestions or requests from embassies or implementers (mostly NGOs) submitting proposals. In the fall of 2012, along with designating a formal R2P focal point, it began designating already existing crisis prevention projects as $\mathrm{R} 2 \mathrm{P}$ projects to be able to respond to international or civil society questions about its operational footprint. Of course, the distinction between crisis, conflict, and atrocity prevention is usually more relevant at the analytical stage (to avoid missing certain risks) than at the level of programming.

An even larger proportion of the increased spending-hundreds of millions of euros per year in recent years - goes into civilian stabilization projects. Again, there is no formal distinction made between funding for atrocity prevention or R2P. Many of these projects seek to re-establish basic public services along with the social fabric of communities after civil war, displacement, and/ or atrocities. Iraq, Afghanistan and Libya, among others, are priority countries. In recent years, some of this support went to supporting communities outside government or extremist control in Syria. Some projects promote inter-ethnic reconciliation or similar efforts that might be considered contributions to atrocity prevention in particular, while others follow merely broadly similar goals. However, despite significant conceptual investments into the improvement of programming for

\footnotetext{
${ }^{13}$ Brockmeier, The Future of Germany's Support.
} 
crisis prevention and stabilization at large, the role of atrocity prevention or R2P in decisions about priority countries or program design remains unaddressed.

\section{Early Warning}

A prerequisite for prevention is the ability of government bureaucracies to develop appropriate strategic policy options at an early stage and in every new phase of escalation. In most cases, however, violence escalates while the pressure to act only mounts as a response to media attention, at which point it is too late for most forms of prevention. As in other countries, German decision-makers are then too often confronted with the choice between either authorizing a military interventionwith all the associated political and practical risks of such an intervention, which translate into significant obstacles for such a decision-or just standing by while the slaughter unfolds.

For this reason, it is critically important to create political instruments that provide a wider range of policy options at all stages of violent escalation ${ }^{14}$ and increase the government's capacity to detect crises early. Related to the lack of coordination structures in the German administration, there are several individual early warning tools by different ministries, but no opportunities to analyze their results together and adjust the German government's strategy and programing accordingly.

While the foreign ministry draws on its embassies, there is little incentive for individual ambassadors to raise the alarm bells. Diplomats themselves are overextended, since embassies in at-risk countries are often too small and their freedom of movement is restricted. In some cases, embassies have been closed precisely at a time at which particularly close monitoring of the situation would have been decisive. There is no training for the diplomatic corps or embassy personnel on R2P or the risk factors in atrocity prevention (let alone for intelligence agents or development workers). Aid workers regularly complain about the lack of reporting from the government on violence and conflict risks, while government representatives prohibit them from publicizing their own earlywarning analyses. The Ministry for Economic Cooperation and Development commissions annual country assessments by the German Institute of Global and Area Studies, which classifies the 90 countries that the ministry works in into three categories: low risk of conflict, increased risk of conflict, acute risk of conflict. This traffic light-style system is supposed to guide country desk officers in longer-term programming decisions and is shared with the Foreign Office, but there is no systematic, unified approach by the whole government to assessing the results of the different early warning instruments and devising a response.

The situational awareness provided by the intelligence services with regard to atrocities is even more deficient, largely because threats to Germany dominate the mission of the Federal Intelligence Service (Bundesnachrichtendienst, BND) ${ }^{15}$ Meanwhile, German military advisors serving in fragile countries are not even required to report on conflict or atrocity risks. Some of them consider any kind of critical reporting on local partners, even within their confidential internal channels, as damaging to their trust-building mission.

\section{Mediation Capacities and Sanctions}

The new government guidelines on crisis prevention and peacebuilding identify German support to mediation initiatives as a priority and commit the government to strengthening its own capacities as well as those of international institutions. The government also promises to appoint more highranking special envoys for specific crises. Germany might also be able to increase its support to mediation capacities on a European level; in many cases, the EU as a whole can be better placed to mediate than individual member states. In recent years, the Mediation Support Team within the European External Action Service (EEAS) has provided technical support to mediation processes in Mali, Myanmar, Lebanon, South Sudan, CAR, and Ukraine. ${ }^{16}$

\footnotetext{
${ }^{14}$ Compare to Samantha Power, A Problem from Hell: America and the Age of Genocide (New York: Basic Books, 2002).

${ }^{15}$ German Federal Government, "Konfliktregionen weltweit," Bundesnachrichtendienst, accessed November 10, 2017, http://www.bnd.bund.de/DE/Themen/Lagebeitraege/Konfliktregionen/Konflikte node. html;jsessionid=7B3B77A151CA04D165390DFA3075F070.2 cid377.

${ }^{16}$ European External Action Service, Factsheet EU Mediation Support Team, EEAS, accessed November 10, 2017, http://eeas.
} 
Similarly, the guidelines promise to strengthen targeted sanctions and sanctions regimessomething that the German government would do through the European Union as well. The threat or imposition of targeted sanctions such as visa and travel bans, or the freezing of assets against individual perpetrators, is one tool at the disposal of the international community to deter atrocities. In comparison to the United States, the EU's capacity to impose and monitor targeted sanctions remains very weak. While more than 180 people are dedicated to designing and implementing sanctions at the US Treasury, some US policymakers complain that they face just a handful of people at the EEAS to deal with the measures ${ }^{17}$ Here the EU could learn from the US experience, as well as review its own lessons from previous sanctions regimes. ${ }^{18}$ Strengthening the EU's capacity to design and impose sanctions will also allow it to engage more with the United States on the legal questions concerning listings of individuals. The required legal changes include improving the legal framework for sanctioning individuals so that well-founded travel and financial sanctions will be more difficult for perpetrators to challenge in the European Court for Human Rights.

\section{Conflict-Sensitive Development Cooperation}

In the context of Germany's system of strong ministerial autonomy, the fact that R2P belongs, so to speak, to the Foreign Office has long been a convenient excuse for other ministries to avoid participating in any possibly controversial discussion on their potential contributions to atrocity prevention. This is regardless of the fact that several other ministries have been responsible for important contributions to atrocity prevention themselves. While atrocity prevention or R2P are thus not formally recognized as relevant issues by the German development apparatus, there is a longstanding commitment (with its associated institutional backbone) to contributing to conflict prevention, security, and peacebuilding in development cooperation. The Ministry for Economic Cooperation and Development has a policy division for "peace \& security and disaster risk reduction," and the implementing agencies have their own departments on peace and conflict reduction.

Around two-thirds of the partner countries of German development cooperation are fragile or in conflict. The Ministry for Economic Cooperation and Development and its main implementing agencies, the KfW banking group and the Gesellschaft für Internationale Zusammenarbeit (GIZ), claim to implement conflict-sensitive development programming and to follow a do-no-harm approach. Their analytical foundation for doing so is the country-specific traffic light assessment mentioned above as well as an internal GIZ classification of countries at risk of conflict. Both lists are updated once a year. If a given country is marked yellow or red in the annual analysis, the corresponding programs need to conduct a so-called peace and conflict assessment. This assessment (in theory) includes an analysis of the main conflict drivers and key actors, identifies development needs related to the risk factors, outlines options for contributions to peacebuilding that the suggested project could deliver, describes external risks, and suggests ways to monitor the implementation of such projects. ${ }^{19}$ In this context, there should be trainings for all employees in risk management and conflict sensitivity in crises countries.

In reality, the degree of conflict sensitivity for any given program depends very much on the country context and its staff. In some cases, conflict sensitivity has been exclusively understood as reputational risk management for GIZ or its implementing partners, not as minimizing the risk that a given project escalates a conflict. In some countries - in particular those that receive a high level of political attention in Berlin - time and pressure to spend money is so high, that there is no time for proper analysis, trainings, or check-ins for and with implementing partners. ${ }^{20}$

europa.eu/factsheets/docs/factsheet eu-mediation-support-team en.pdf.

${ }^{17}$ Interview with policymaker at the US Treasury Department, March 2015, Washington, D.C.

${ }^{18}$ Mark Leonard, “A vision for the EU's new foreign policy strategy," European Council on Foreign Relations, April 24, 2015, accessed November 10, 2017, http://www.ecfr.eu/article/commentary a vision for the eus new foreign policy strategy3006.

${ }^{19}$ GIZ, Safeguard Konflikt und Kontextsensibilität, Guidance note for staff, on file with authors, January 2017.

${ }^{20}$ Interviews with GIZ employees, evaluators of GIZ projects and officials of the German Federal Foreign Office and the Federal Ministry for Economic Cooperation and Development, throughout 2017. 
Support to International Criminal Justice Mechanisms

An area in which the German administration has made promising progress in 2017 is international criminal justice - again without labeling it atrocity prevention or as relevant to R2P, as was the case with development cooperation. Until recently, the baseline for German or EU contributions to the national or international criminal prosecution of atrocity perpetrators was low. ${ }^{21}$ The German Federal Criminal Police (Bundeskriminalamt) has a "Central Unit for the Fight against War Crimes and further Offences pursuant to the Code of Crimes against International Law," which cooperates with the war crimes units of international police services in the EU Genocide Network, with the International Criminal Court, as well as with Europol and Interpol. The level of staffing remains low, and witness protection as well as stakeholder involvement require improvement. ${ }^{22}$

The influx of almost a million refugees from Syria and the introduction of universal jurisdiction in German law has led to significant developments. First, the Federal Prosecutor is investigating cases in which suspected Syrian war criminals are now on German soil. As of late 2017, German authorities have conducted 27 investigations against individuals for war crimes committed in Syria or Iraq, as well as two wide-ranging investigations about Syrian war crimes (so-called structural investigations without targeting a particular accused individual). Four of the individual cases have been brought to trial on charges of war crimes or crimes against humanity, in addition to 45 cases based on terrorism charges. ${ }^{23}$

Second, it seems that the German Federal Prosecutor is willing to, for the first time, apply the principle of universal jurisdiction and prosecute high-ranking members of the Assad regime for war crimes or crimes against humanity. The so-called principle of opportunity has so far given German prosecutors an out from prosecuting war criminals worldwide (something that would theoretically be possible within German law). The principle stipulates that if perpetrators are not in Germany, do not have German citizenship, and the prosecution has little chances for success, the Office of the Federal Prosecutor (Bundesanwaltschaft) can decide against taking up such as case. On Syria, however, the fact that thousands of potential victims and witnesses now live in Germany and that there is more available evidence gathered on the crimes of Syrian regime members, has significantly increased the chances of success. In mid-2017, the Federal Prosecutor General (Generalbundesanwalt) seemed willing to bring a case against key members of the Assad regime to trial (in absentia) in Germany. In the fall of 2017, the Federal Prosecutor was handed the socalled "Ceasar" files, which had been smuggled out of Syria years earlier and document systematic torture in Syrian prisons with photographic evidence. The German Federal Prosecutor is the first judicial authority worldwide that could use evidence to issue international arrest warrants against key members of the Assad regime.

\section{Military Contributions}

Despite a growing readiness to deploy German troops, military interventions remain controversial and their mixed results have only reinforced a tendency to be skeptical about the utility of military force to achieve political objectives among the German strategic community. Accordingly, for the Ministry of Defense, atrocity prevention is a difficult issue in several ways. Despite $82 \%$ support in polls for using the military to "prevent acts of genocide" 24 and the fact that the public had little

\footnotetext{
${ }^{21}$ Despite the massacre in Andijan/Uzbekistan (2005) and the EU sanctions, the German armed forces continued its military training program; the erstwhile Uzbek Interior Minister, Sakir Almatow, the person with primarily responsible for "Andijan," traveled to Germany in November 2005 on "humanitarian grounds" and received treatment in a private clinic in Hannover. On criminal law actions against war criminals in Germany: Dominic Johnson, Simone Schlindwein, and Bianca Schmolze, Tatort Kongo - Prozess in Deutschland. Die Verbrechen der ruandischen Miliz FDLR und der Versuch einer juristischen Aufarbeitung (Berlin: Ch. Links Verlag, 2016).

${ }^{22}$ Wolfgang Kaleck, "Keine Straflosigkeit bei Kriegsverbrechen - Völkerstrafprozesse in Deutschland voranbringen," Anhörung im Ausschuss für Recht und Verbraucherschutz des Deutschen Bundestages (statement, Berlin, April 25, 2016), European Center for Constitutional and Human Rights, accessed December 31, 2017, https://www.bundestag. de/blob/419958/16a05fb20339cecc383b10dba5835b10/ecchr-data.pdf.

${ }^{23}$ Human Rights Watch, “These Are the Crimes We Are Fleeing” Justice For Syria In Swedish and German Courts, October 2017, accessed December 31, 2017, https://www.hrw.org/sites/default/files/report pdf/ijsyria1017 web.pdf.

${ }^{24}$ Körber Foundation, Einmischen oder zurückhalten? Ergebnisse einer repräsentativen Umfrage von TNS Infratest
} 
objection to arming and training the Kurdish Peshmerga since 2014, the measure is still considered unpopular. Preventing or stopping atrocities is also widely seen as irresponsible overreach among the military itself and the strategic community, partly due to a lack of expeditionary capabilities and partly because of a lack of familiarity with specific operational and tactical scenarios such as those developed in the Mass Atrocity Response Operations (MARO) project in the US or similar work in Norway. ${ }^{25}$ As a result, neither the Defense Ministry as an institution nor any incumbent ministers have anything to gain politically by actively looking for expeditionary adventures.

The most likely scenario for a German military contribution to preventing atrocities in the coming years is through its growing participation in UN peace operations. Since 2015, up to 600 soldiers have been serving with the UN peacekeeping mission in Mali. This tripled German participation in peacekeeping, which had thus far been limited to contributions to the UN Interim Force in Lebanon and to a few soldiers each in South Sudan, Darfur, and Liberia, among other places. At the same time, the German government presents its participation in Mali not as a contribution to strengthening the UN peacekeeping system and the protection of civilians, but as a contribution to the fight against terrorism. Similarly, the government contributed to the anti-IS coalition as a response to French demands.

It is still likely that German contributions to peacekeeping will further increase in the next four years, and since most peacekeeping operations are mandated to protect civilians, it would be high time for the German military to familiarize itself with the practical challenges of this particular mission. So far, there is no doctrine on operational or tactical protection of civilians (POC) in the Bundeswehr that goes beyond the basics of international humanitarian law.

The other military pillar that Germany is likely to expand in the coming years is military assistance. A new $€ 100 \mathrm{~m}$ train and equip program, created in 2016, partly aims to build the capacity of reliable military contributors to UN, African Union (AU), and other peace operations, particularly in Africa and the Middle East. This program is set to expand along with a similar police training component and an older, slightly smaller non-lethal equipment and advisory program. As the specific projects under these programs move from their historical focus on logistics and medical support toward frontline capabilities, a focus on operational and tactical protection of civilians and broader atrocity prevention scenarios such as safe zones will become increasingly relevant as well. ${ }^{26}$

Engaging Emerging Powers and Rebuilding Effective International Order

Since the global political fallout over NATO's abuse of the UN Security Council resolution for military intervention in Libya $2011,{ }^{27}$ leading powers have been unable to find common ground to discharge their duties in safeguarding international peace and security. The most glaring example has been the war in Syria. Most major supporters of atrocity prevention turned their attention away from the multilateral promotion of atrocity prevention toward internal, operational instruments they were able to improve regardless of the multilateral environment. At the same time, atrocities take place in a permissive political climate. In an increasingly contested world order, technical instruments such as prevention, stabilization and development projects through

Politikforschung zur Sicht der Deutschen auf die Außenpolitik [Get in or Keep out? Results of a representative survey by TNS Infratest Policy Research about the View of Germans on Foreign Policy], October 2014, accessed February 20, 2018, http://www.aussenpolitik-weiter-denken.de/fileadmin/user upload/allgemein/Koerber-Stiftung Umfrage Aussenpolitik Broschuere.pdf.

${ }^{25}$ Stephen F. Burgess, "Comments on the Mass Atrocity Prevention Response Operations (MARO) Handbook," Genocide Studies and Prevention: An International Journal 6, no. 1 (2011), 66-69, accessed December 31, 2017, http:// scholarcommons.usf.edu/gsp/vol6/iss1/9; Stian Kjeksrud, Alexander W. Beadle, and Petter H.F. Lindqvist, "Protecting Civilians from Violence: A Threat-Based Approach to Protection of Civilians in UN Peace Operations," (Oslo: FFI and NODEFIC, 2016), accessed December 31, 2017, https://www.ffi.no/no/Publikasjoner/Documents/Protecting-Civiliansfrom-Violence.pdf.

${ }^{26}$ One of the authors developed more detailed recommendations along these lines in Andreas Heinemann-Grüder and Philipp Rotmann's contribution to the Peace Report 2017. Heinemann-Grüder and Rotmann, Practical Implementation of Prevention.

${ }^{27}$ Sarah Brockmeier, Oliver Stuenkel, and Marcos Tourinho, "The Impact of the Libya Intervention Debates on Norms of Protection," Global Society 30, no. 1 (2016), 113-133. 
criminal prosecutions, sanctions, mediation, or military force alone will not stop atrocities. In many cases, Syria or Burundi being just two of the most obvious current examples, preventing atrocities remains foremost a problem of international political order. ${ }^{28}$

For the UN Security Council to overcome its paralysis on atrocity prevention, the Council needs to address the danger of mandate abuse. Germany, which is seeking another two-year nonpermanent seat for 2019 and 2020, could play a pivotal role in building bridges, having abstained from the ill-fated mandate for the military intervention in Libya together with the later critics Brazil, India, Russia and China. Germany could use the Brazilian proposal for "Responsibility while Protecting" (RwP) as a starting point in such an endeavor. Brazil proposed the idea in late 2011, frustrated with how the Libya intervention had turned into regime change with no checks by the UN Security Council. At the time, the initiative fell flat, ${ }^{29}$ but the substantive proposals continue to be worth another serious look.

RwP focused on two areas that are of continued interest to Germany: the criteria for the use of force to protect civilians, and the creation of accountability mechanisms for the use of force. Given the controversies surrounding Resolution 1973, it is unlikely that the Security Council will ever again pass a resolution to protect civilians with all necessary means without also installing checks or regulations that give the council more control over an intervention. ${ }^{30}$

\section{Conclusion}

Slowly, Germany is making progress on atrocity prevention, but the issue is far from playing a key role in Berlin. As our review of Germany's bureaucratic structures on atrocity prevention has shown, German contributions to atrocity prevention - whether diplomatic, financial, conceptual or military - will not fill the gap created by the US retreat in this area any time soon. This is equally the case for other countries in the European Union and the EU as a whole. Much of the recent progress, both on the operational and on the doctrinal levels, is the result of nimble bureaucratic entrepreneurship rather than popular political mobilization or effective lobbying by civil society. Civil servants, as the name implies, are servants of state and society. More domestic political and civil society leadership will be required to realize Germany's stated commitments to preventing genocide and mass atrocities.

\section{Note}

This article draws on previous publications by the authors, including Sarah Brockmeier, Gerrit Kurtz, and Philipp Rotmann, "Schutz und Verantwortung: Über die US-Außenpolitik zur Verhinderung von Gräueltaten" Berlin: Heinrich-Böll-Stiftung \& Global Public Policy Institute, 2013; Tessa Alleblas, et al, "In the Shadow of Syria. Assessing the Obama Administration's Efforts on Mass Atrocity Prevention," Policy Brief (Hague Institute for Global Justice and Global Public Policy Institute, April 2017); Sarah Brockmeier, Julian Junk, and Gerrit Kurtz, "Emerging Norm and Rhetorical Tool: Europe and a Responsibility to Protect," Conflict, Security \& Development 14, no. 4 (2014), 429-460; Sarah Brockmeier, "The Future of Germany's support to the Responsibility to Protect," in Shifting Power and Human Rights Diplomacy, eds. Doutje Lettinga and Lars van Troost (Amsterdam: Amnesty International Netherlands, October 2016), 73-81; Andreas HeinemannGrüder and Philipp Rotmann, "Practical Implementation of Prevention: Outlaw the Violence, Protect the People," In Peace Report 2017: A Selection of Texts, eds. Bruno Schoch, et al (Zurich: Lit Verlag GmbH \& Co. KG Wien, 2017), 54-68.

\footnotetext{
${ }^{28}$ Philipp Rotmann, Gerrit Kurtz, and Sarah Brockmeier, "Major Powers and the Contested Evolution of A Responsibility To Protect," Conflict, Security \& Development 14, no. 4 (2014), 355-377; Gerrit Kurtz and Philipp Rotmann, "The Evolution of Norms of Protection: Major Powers Debate the Responsibility to Protect," Global Society 30, no. 1 (2016), 3-20.

${ }^{29}$ Sarah Brockmeier, Oliver Stuenkel, and Marcos Tourinho, “'Responsibility While Protecting': Reforming R2P Implementation," Global Society 30, no. 1 (2016), 134-150.

${ }^{30}$ Thorsten Benner et al, Effective and Responsible Protection from Atrocity Crimes: Toward Global Action, Global Public Policy Institute (April 2015), 25.
} 


\section{Acknowledgements}

The authors are grateful to Aurélie Domisse for research assistance.

\section{Bibliography}

Alleblas, Tessa, Eamon Aloyo, Sarah Brockmeier, Philipp Rotmann, and Jon Western. "In the Shadow of Syria. Assessing the Obama Administration's Efforts on Mass Atrocity Prevention." Policy Brief. Hague Institute for Global Justice and Global Public Policy Institute, April 2017.

Benner, Thorsten, Sarah Brockmeier, Erna Burai, C.S.R. Murthy, Christopher Daase, J. Madhan Mohan, Julian Junk, Xymena Kurowska, Gerrit Kurtz, Liu Tiewa, Wolfgang Reinicke, Philipp Rotmann, Ricardo Soares de Oliveira, Matias Spektor, Oliver Stuenkel, Marcos Tourinho, Harry Verhoeven, and Zhang Haibin. Effective and Responsible Protection from Atrocity Crimes: Towards Global Action. Global Public Policy Institute, April 2015.

Brockmeier, Sarah. "Germany and the Intervention in Libya." Survival Global Politics and Strategy 55, no. 6, (2013): 63-90. https://doi.org/10.1080/00396338.2013.862937

-------. "The Future of Germany's support to the Responsibility to Protect." In Shifting Power and Human Rights Diplomacy, edited by Doutje Lettinga and Lars van Troost, 73-81. Amsterdam: Amnesty International Netherlands, October 2016.

Brockmeier, Sarah, Gerrit Kurtz, and Julian Junk. "Emerging Norm and Rhetorical Tool: Europe and a Responsibility to Protect." Conflict, Security and Development 14, no. 4 (2014): 448-449. https://doi.org/10.1080/14678802.2014.930587

Brockmeier, Sarah, Gerrit Kurtz, and Philipp Rotmann. "Schutz und Verantwortung: Über die USAußenpolitik zur Verhinderung von Gräueltaten." Berlin: Heinrich-Böll-Stiftung \& Global Public Policy Institute, 2013.

Brockmeier, Sarah, Julian Junk, and Gerrit Kurtz. "Emerging Norm and Rhetorical Tool: Europe and a Responsibility to Protect." Conflict, Security \& Development, 14, no. 4 (2014): 429-460. https://doi.org/10.1080/14678802.2014.930587

Brockmeier, Sarah, Oliver Stuenkel, and Marcos Tourinho. "The Impact of the Libya Intervention Debates on Norms of Protection." Global Society 30, no. 1 (2016): 113-133. https://doi.org/10 $.1080 / 13600826.2015 .1094029$

. "'Responsibility While Protecting': Reforming R2P Implementation." Global Society 30, no. 1 (2016): 134-150. https://doi.org/10.1080/13600826.2015.1094452

Budapest Centre for the International Prevention of Genocide and Mass Atrocities. The EU and the Prevention of Mass Atrocities - An Assessment of Strengths and Weaknesses. Hungary: Foundation for the International Prevention of Genocide and Mass Atrocities, February 2013. Accessed December 31, 2017. http://massatrocitiestaskforce.eu/Report files/The EU and the prevention of mass atrocities - an assessment of strenghts and weaknesses.pdf.

Burgess, Stephen F. "Comments on the Mass Atrocity Prevention Response Operations (MARO) Handbook." Genocide Studies and Prevention: An International Journal 6, no. 1 (2011), 66-69. Accessed December 31, 2017. http://scholarcommons.usf.edu/gsp/vol6/iss1/9.

De Franco, Chiara, Christoph O. Meyer, and Karen E. Smith. "Living by Example?' The European Union and the Implementation of the Responsibility to Protect (R2P)." Journal of Common Market Studies, 53, no. 5 (2015): 994-1009. https://doi.org/10.1111/jcms.12240

European External Action Service. Factsheet EU Mediation Support Team. EEAS. Accessed November 10, 2017. http://eeas.europa.eu/factsheets/docs/factsheet eu-mediation-support-team en.pdf.

German Federal Government. Guidelines on Preventing Crises, Resolving Conflicts, Building Peace. July 21, 2017. German Federal Foreign Office. Accessed December 31, 2017. http://www.diplo. de/guidelines.

-------. "Konfliktregionen weltweit." Bundesnachrichtendienst. Accessed November 10, 2017. http://www.bnd.bund.de/DE/Themen/Lagebeitraege/Konfliktregionen/Konflikte node. html;jsessionid=7B3B77A151CA04D165390DFA3075F070.2 cid377.

GIZ. Safeguard Konflikt und Kontextsensibilität. Guidance note for staff, on file with authors. January 2017. 
Heinemann-Grüder, Andreas and Philipp Rotmann. "Practical Implementation of Prevention: Outlaw the Violence, Protect the People." In Peace Report 2017: A Selection of Texts, edited by Bruno Schoch, Andreas Heinemann-Grüder, Corinna Hauswedell, Jochen Hippler, and Margret Johannsen, 54-68. Zurich: Lit Verlag GmbH \&Co. KG Wien, 2017.

Hofmann, Gregor. „Politische Bekenntnisse ohne Folgen.“ HSFK Standpunkte 6 (2013): 1- 12.

Human Rights Watch. "These Are the Crimes We Are Fleeing" Justice for Syria In Swedish and German Courts. October 2017. Accessed December 31, 2017. https://www.hrw.org/sites/default/ files/report pdf/ijsyria1017 web.pdf.

Johnson, Dominic, Simone Schlindwein, and Bianca Schmolze. Tatort Kongo - Prozess in Deutschland. Die Verbrechen der ruandischen Miliz FDLR und der Versuch einer juristischen Aufarbeitung. Berlin: 2016.

Kaleck, Wolfgang. "Keine Straflosigkeit bei Kriegsverbrechen - Völkerstrafprozesse in Deutschland voranbringen." Anhörung im Ausschuss für Recht und Verbraucherschutz des Deutschen Bundestages. Statement, Berlin, April 25, 2016. European Center for Constitutional and Human Rights. Accessed December 31, 2017. https://www.bundestag. de/blob/419958/16a05fb20339cecc383b10dba5835b10/ecchr-data.pdf.

Kjeksrud, Stian, Alexander W. Beadle, and Petter H.F. Lindqvist. "Protecting Civilians from Violence: A Threat-Based Approach to Protection of Civilians in UN Peace Operations." Oslo: FFI and NODEFIC, 2016. Accessed December 31, 2017. https://www.ffi.no/no/ Publikasjoner/Documents/Protecting-Civilians-from-Violence.pdf.

Körber Foundation. Einmischen oder zurückhalten? Ergebnisse einer repräsentativen Umfrage von TNS Infratest Politikforschung zur Sicht der Deutschen auf die Außenpolitik [Get in or Keep out? Results of a representative survey by TNS Infratest Policy Research about the View of Germans on Foreign Policy]. October, 2014. Accessed February 20, 2018. http://www. aussenpolitik-weiter-denken.de/fileadmin/user upload/allgemein/Koerber-Stiftung Umfrage Aussenpolitik Broschuere.pdf.

Kurtz, Gerrit and Philipp Rotmann. "The Evolution of Norms of Protection: Major Powers Debate the Responsibility to Protect." Global Society 30, no. 1 (2016): 3-20. https://doi.org/10.1080/1 $\underline{3600826.2015 .1092425}$

Leonard, Mark. "A vision for the EU's new foreign policy strategy." European Council on Foreign Relations. April 24, 2015. Accessed November 10, 2017. http://www.ecfr.eu/article/ commentary a vision for the eus new foreign policy strategy 3006 .

Power, Samantha. A Problem from Hell: America and the Age of Genocide. New York: Basic Books, 2002.

Rotmann, Philipp, Gerrit Kurtz and Sarah Brockmeier. "Major Powers and the Contested Evolution of a Responsibility To Protect." Conflict, Security \& Development 14, no. 4 (2014): 355-377. https://doi.org/10.1080/14678802.2014.930592

Steinbrecher, Markus, Heiko Biehl, Chariklia Höfig, and Meike Wanner. Security and Defense Policy Opinion climate in the Federal Republic of Germany. Potsdam: Centre for Military History and Social Sciences of the German Armed Forces, 2016. Accessed December 31，2017. http://www.mgfa-potsdam.de/html/einsatzunterstuetzung/ downloads/161124kurzberichtbevoelkerungsumfragezmsbw2016.pdf

Vick, Karl and Simon Shuste. "Time Person of the Year: Chancellor of the Free World." TIME, December 9, 2015. Accesed December 31, 2017. http://time.com/time-person-of-the-year2015-angela-merkel/.

Wiesel, Elie. "Genocide Prevention Initiative Launch." Speech, Washington, DC, April 23, 2012. United States Holocaust Memorial Museum. Accessed February 20, 2018. https://www. youtube.com/watch?v= xTGJxYp76w. 